\title{
THE ROLE OF THE TEACHER IN THE FORMATION OF THE STUDENT - CITIZEN WITHIN THE PUBLIC SCHOOL IN HIGH SCHOOL: A REFLECTION DONE FROM EXPERIENCES AS A RESIDENT IN THE PEDAGOGICAL RESIDENCE PROGRAM
}

O Papel Do Professor Na Formação Do Aluno - Cidadão Dentro Da Escola Pública No Ensino Médio: Uma Reflexão Feita A Partir Das Experiências Como Residente No Programa Residência Pedagógica

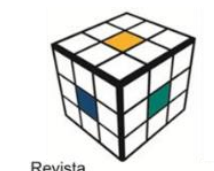

Miliane Moreira Cardoso Vieira ${ }^{1}$, Abimael Junior Souza Santos² ${ }^{2}$ Jaiara Martins Aguiar Monteiro ${ }^{3}$.

${ }^{1}$ Docente do Curso de Graduação em Letras - Língua Inglesa e Literaturas, Universidade Federal do Tocantins UFT, Araguaína, Tocantins, Brasil.

${ }^{2}$ Graduando do Curso de Graduação em Letras - Língua Inglesa e Literaturas, Universidade Federal do Tocantins, Araguaína, Tocantins, Brasil.

${ }^{3}$ Professora da Educação Básica, Secretaria de Estado da Educação, Juventude e Esportes do Tocantins - SEDUC, Araguaína, Tocantins, Brasil.

Artigo recebido em 01/04/2020 aprovado em 20/04/2020 publicado em 20/04/2020.

\section{INTRODUCTION}

This work brings experiences lived in an Elementary School and a High School, exposing the main difficulties in learning a new language and the challenges that English language teachers need to face in the exercise of the function, under the resident's gaze. Knowing that, socioeconomic and cultural conditions are two influencing factors in the teaching and in the notion of being a citizen by the student. In this way, we also show the teacher as a trainer of these citizens and the influence of the foreign language in this formation, dedicating a look to the foreign language as an instrument of insertion of these students, in an increasingly technological, communicative and globalized world.

\section{METHODOLOGIES AND MATERIALS}

While pedagogical residency time, I used to teach together a partner. My partner and I worked alternately in the classes. We divided the classes into two parts: while one explained part of the content, the DOI: http://dx.doi.org/10.20873/uftsupl2020-8783 other paid attention to the classroom students and helped if any student had any questions. And right after the roles were reversed. This happened when we had three classes to teach. When the classes decreased from three to two, each resident was left with one class and at that moment we had the role of just watching and assisting the classroom students while the other taught.

The profile of the High School classes was teenagers from 15 to 17 years old, mostly from outlying communities of the city, who had difficulty even getting to school, and who had a thought that they would not use the English language for anything in their lives. However, they were energetic teenagers ready to be exploited and exposed to a new way of learning English.

What caught my attention in High School classes was that although they thought that the English language was of no use in their lives, they were very curious and always sought to answer their

Revista Desafios - v. 7, n. Supl. RP-UFT, 2020 
questions by asking "teacher, how can I say this or that in English?", "Can I go to the restroom? or "How can I say that I live in a certain neighborhood?" This indirectly showed them the need to learn English and made us understand our role as foreign language teachers in the social development of these students, since

The concept is very broad and heterogeneous, but it is understood that "being a citizen" involves understanding what position / place a person (the student, the citizen) occupies in society. That is, where does he speak of in society? Why is this one position? How did you get there? Does he want to be in here? Does he want to change it? Does he want to get out of it? What does this position include or exclude from? From this perspective, as far as language teaching is concerned, the Foreign Languages subject may include the development of citizenship. (BRAZIL, OCEM, 2006, p. 91) ${ }^{1}$

Their willingness to learn and show that they knew it was also positive. We did activities in the classroom and asked them to respond; automatically they offered themselves to respond. The autonomy of the classroom students was something that made our teaching much easier. Watching the students themselves answering the activities with our help or alone was significant for us. This autonomy point was a way for me and my partner to evaluate the classes, placing the student as protagonist and not just as a listener in the classroom, because

[... protagonism is activated by the construction of autonomy, whether in the production of written and oral texts in a foreign language, or in the research process in written sources, in which the student has the role of

\footnotetext{
${ }^{1}$ Admite-se que o conceito é muito amplo e heterogêneo, mas entende-se que "ser cidadão" envolve a compreensão sobre que posição/lugar uma pessoa (o aluno, o cidadão) ocupa na sociedade. Ou seja, de que lugar ele fala na sociedade? Por que essa é a sua posição? Como veio parar ali? Ele quer estar nela? Quer mudá-la? Quer sair dela? Essa posição o inclui ou o exclui de quê? Nessa perspectiva, no que compete ao ensino de idiomas, a disciplina Línguas Estrangeiras pode incluir o desenvolvimento da cidadania. (BRASIL, OCEM, 2006, p. 91)

DOI: http://dx.doi.org/10.20873/uftsupl2020-8783
}

selecting pertinent information, structuring and organizing it in appropriate and consistent way. This process implies the understanding by students and teachers that each individual should be able to appropriate knowledge and discern ways of making use of it. (BRAZIL, PCN+, 2002, p. 96) $)^{2}$

\section{RESULTS AND DISCUSSIONS}

Student's autonomy was also noticed when they came up with exercise answers, often not exactly in the same words as the right answer would be, but if the idea was the same, we considered it. Teaching at Elementary and High school had few differences. Note that the Elementary students were more understanding and obedient to the teacher. Because they are pre-adolescent and still have that responsible person's view of them. In High School the rebellion of adolescence became the difference, but something understandable. However, Elementary and High School students were participative and they shared the same skills: the autonomy. Students were curious and ready to do any activity that the teachers presented.

What made it a little difficult for us to teach was the lack of technological resources, since we were working with pre-teens and teenagers. As a result, our classes could not be totally masterful, neither monotonous. In two or three lessons a month we needed to bring something different: a song, a video, an out-of-class activity, an interdisciplinary activity. And when we needed to do this kind of activity, we lacked resources such as: internet, computers, data show, and speakers. But as a teacher

\footnotetext{
2 Ativa-se o protagonismo pela construção da autonomia, seja na produção de textos escritos e orais em língua estrangeira, seja no processo de pesquisa em fontes escritas, em que cabe ao aluno o papel de selecionar informações pertinentes, estruturá-las e organizá-las de modo apropriado e coerente. Esse processo implica a compreensão, por parte de alunos e professores, de que cada indivíduo deve ser capaz de apropriar-se do conhecimento e discernir quanto a maneiras de fazer uso dele. (BRASIL, PCN+, 2002, p. 96)
}

Revista Desafios - v. 7, n. Supl. RP-UFT, 2020 
in our country it is a constant challenge, so we overcame these obstacles in our own way.

During these eighteen months of pedagogical residence, we organized important events involving the English classes at school. The English music festival and the English Gymkhana were events that brought interaction between Elementary and High School classes. In these events we were able to explore all the content worked in the classroom through music and quiz games. The interaction between the English classes was positive, too. The interdisciplinarity and the involvement of other teachers in the developed activities were something wonderful. It enabled us to work the English language in other spheres.

\section{CONCLUSION}

Teaching English with the purpose of bringing students closer to the knowledge world helped us to transform students' view of the English language. Showing them that English is a form of individual and cultural interaction with the world, made them cling more to the language and bring their everyday experiences into the classroom. So we understand that

A foreign language teacher in High School should use students' linguistic and metalinguistic knowledge, establish points of convergence and contrast, as well as put the student before real situations of language use, which go beyond the theoretic and metalinguistic. (BRAZIL, PCN+, 2002, p.94) ${ }^{3}$

\footnotetext{
${ }^{3} \mathrm{O}$ professor de língua estrangeira no ensino médio deve lançar mão de conhecimentos linguísticos e metalinguísticos dos alunos, estabelecer pontos de convergência e de contraste, assim como colocar o aluno frente a situações reais de uso do idioma, que ultrapassam o teórico e o metalinguístico.
}

The pedagogical residence could make us understand our role as teachers, which is to educate our students as citizens, enabling them to act within the world by exploring their culture and other cultures. Making language an instrument of communication and insertion in an increasingly globalized world. Making the school a place for knowledge exchange and collective knowledge construction.

Todos os autores declararam não haver qualquer potencial conflito de interesses referente a este artigo.

\section{REFERENCES}

BRASIL. Orientações Curriculares Para o Ensino

Médio. Linguagens, Códigos e suas tecnologias. Brasília: MEC, 2006.

\section{BRASIL. Parâmetros Curriculares Nacionais+}

Ensino Médio. Linguagens, Códigos e suas
CASTRO, Solange T. Ricardo de. A Linguagem e a Reconstrução da ação docente: um estudo com professoras de inglês de um curso de Letras. In: MAGAlHÃES, Maria Cecília C. FIDALGO, Sueli Salles. A Linguagem da Exclusão e Inclusão Social na Escola. São Paulo: Unifesp, 2018.

VIEIRA, Miliane Moreira Cardoso. Novas Perspectivas no ensino e na pesquisa Universitária na era da supercomplexidade: inovações quanto ao desenvolvimento da Língua Inglesa através da escrita de relatos reflexivos nas disciplinas de Estágio Supervisionados. In: PINHO, M. J. de; SUANNO, M. V. R.; SUANNO, J. H. Formação do Professor e Interdisciplinaridade: Diálogo Investigativo em Construção. Goiânia: América, 2014, p. 161 - 178. 